\title{
GENERATING WALKERGY SUPPLEMENT FOR STORING ENERGY IN THE BATTERY: BASIS FOR ENERGY CONSUMPTION
}

\author{
Jexter Fabriga, Edrian Ubiadas, Denizon Go, Arjay Capalaran, \\ Prof. Herbert D. Vertucio, \\ Dr. Eriberto R. Astorga, Jr.
}

\begin{abstract}
Energy Consumption is one of the best ways to give emphasis for all nations. It has a great influence to save energy with the continuous stability, growth and development of certain country basis for strong foundations with the establishments of business, market, sales, production and other related aspect of transforming and using energy consumption deals with compassion of nonstop growing economy. Through this, electricity give light the whole nation because of the hightechnologically advance formulas of feasible machines, gadgets and etc. that we are using. Electricity empowers the economic growth and sustainability to stand alone. But on the other hand, too much consumptions of energy were observed throughout the nations. With this, Generating Walkergy Supplement in storing energy in the battery would be a way of energy consumption with the help of Piezoelectricity and Piezoelectric Effect.
\end{abstract}

Jexter Fabriga, Edrian Ubiadas, Denizon Go, Arjay Capalaran,

AMA Computer College

Philippines

Prof. Herbert D. Vertucio,

Arellano University

Philippines

Dr. Eriberto R. Astorga, Jr.

Eulogio "Amang” Rodriguez Institute of Science and Technology

Philippines
Piezoelectricity is the electric charge that accumulates in certain solid materials (such as crystals, certain ceramics, and biological matter such as bone, DNA and various proteins) in response to mechanical stress that resulting from pressure. It is an ancient source of electrical charge. On the other hand, piezoelectric effect is the linear electromechanical interaction between electrical and other mechanical state in crystalline materials. The piezoelectric effect is a reversible process which deformed even slightly, the material will produce electricity and vice versa. If electricity is allocated on the material exhibiting piezoelectric characteristics, the material will be deformed. In line with this study, it will serve as basis for energy consumption of the nation that reliably useful for sustaining economy as a part of integral use of energy.

Keywords: Walkergy, Piezoelectricity, Piezoelectric transducers, Micro electromechanical, Energy Information Administration. 


\section{Introduction}

Energy Consumption relies on different sources of energy pertaining to renewable and non-renewable which is a great help to formulate and generate electricity for the use of the inhabitants. It has a great influence to operate the world-industry through electricity which will give light the whole nation with the hightechnologically advance formulas of practical machines, gadgets, gears, equipments, machineries and apparatus that we are using. The essence of electricity empowers the economic growth and sustainability to stand alone.

Meanwhile, other forms of energy also exist to use which is necessary using the available technologies created by experts and inventors. Such forms of energy have their different use in accordance with its practical applications, specifications, styles, hybrid, terms and conditions to guarantee a source of energy. One of which is Steam from heat which is used to create electrical energy. This is one of many examples of how energy changes its form with the help of other machines or devices. We can then use electrical energy to power our homes which makes our lives easier and comfortable. Based from World Energy Consumption by Sector, 2012 EIA Data, a total of $51.7 \%$ of electricity is consumed at the industrial sector, $26.6 \%$ is used for transportation, $13.9 \%$ is used by residential areas and about $9.8 \%$ is used on commerce. Breaking up the composition of where the electricity used by these sectors came from, $33.1 \%$ is produced using Oil, 30.3\% comes from Coal, $23.7 \%$ from Natural gas, $6.4 \%$ from hydroelectricity, $4.9 \%$ from Nuclear energy, and only a small $1.6 \%$ comes from Renewable energy sources (BP Statistical Review of World Energy, June 2012).
With this, dangerous greenhouse gasses are release when fossil fuels such as oil, coal and natural gasses are used for energy production, and the risk associated with nuclear energy for the health effects of radiation, penetrating deep into a body where radiation destroys cells thereby initiating cancer. Because of this, the demand for the production of clean and renewable energy source or the alternative energy sources are created. These alternatives produce no combustion or radiation of any kind.

Furthermore, Alternative energy sources are the best way to come up with the possible future. Solar, wind, hydro and geothermal energy are examples of these alternatives, but like everything else, these alternatives have their limitations. These are the basis why the proponents or even the researchers came up with the idea of inventing or exploring another alternative source, the exploration of the potentials of piezoelectricity, which will be used to create the feasible effect of the "WALKERGY SUPPLEMENT". Though this, the piezoelectricity and piezoelectric effect is the main conceptualized idea in order to formulate the product for energy consumption. In line with this study, it will serve as basis for energy consumption of the nation that reliably useful for sustaining economy as a part of integral use of energy. 
Proc. of the Intl. Conf. on Advances in Applied science and Environmental Technology - ASET 2015.

Copyright (C) Institute of Research Engineers and Doctors, USA .All rights reserved.

ISBN: 978-1-63248-040-8 doi: 10.15224/ 978-1-63248-040-8-51

\section{Research Focus}

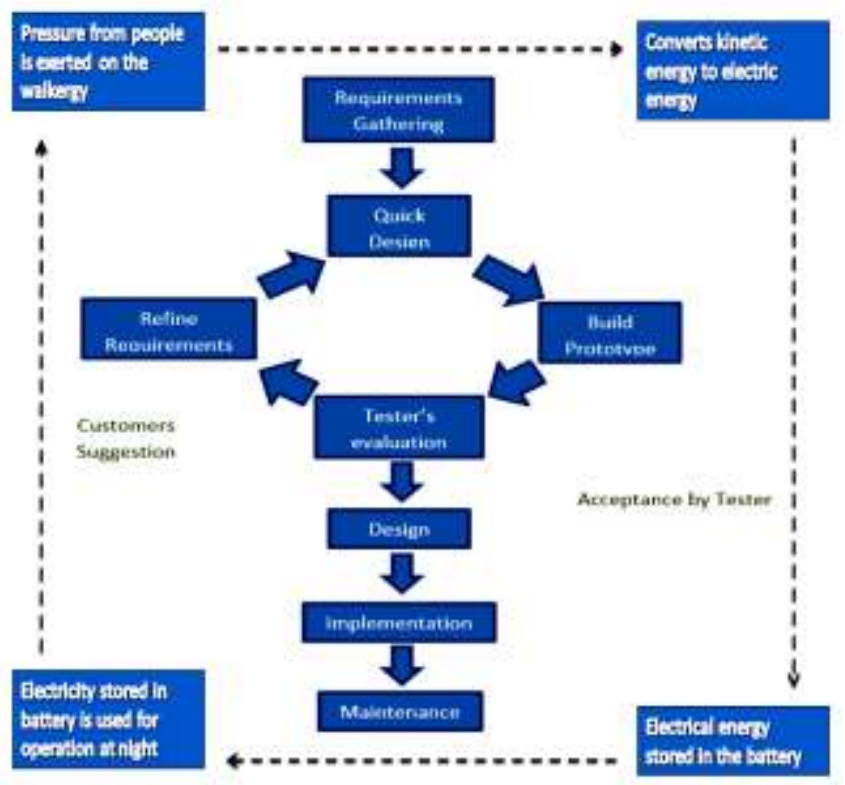

Figure 1.1 Generating Walkergy Supplement for Storing Energy in the Battery: Basis for Energy Consumption

\section{Statement of the Problems}

1. How the cycle of generated Walkergy were structured and developed?

2. What is the projected generation of Walkergy pad in changing rate and generating voltage in terms of:

2.1. Walking;

2.2. Running; and

2.3. Jumping?

3. What is the significant benefit of

Walkergy Pad for an Average

Energy House Consumption?

\section{Research Design}

The experimental method of research was used for this study in order for a systematic and scientific approach that can manipulate one or more variables, controls and measures of any changes in other variables. Though this, the proponents will attest the continuous development of the Walkergy Pad in generating electricity to supply purposively.

\section{Findings of the Study}

1. How the cycle of generated Walkergy were structured and developed?

Table 1. The Experimental Cycle Generation of Walkergy Pad

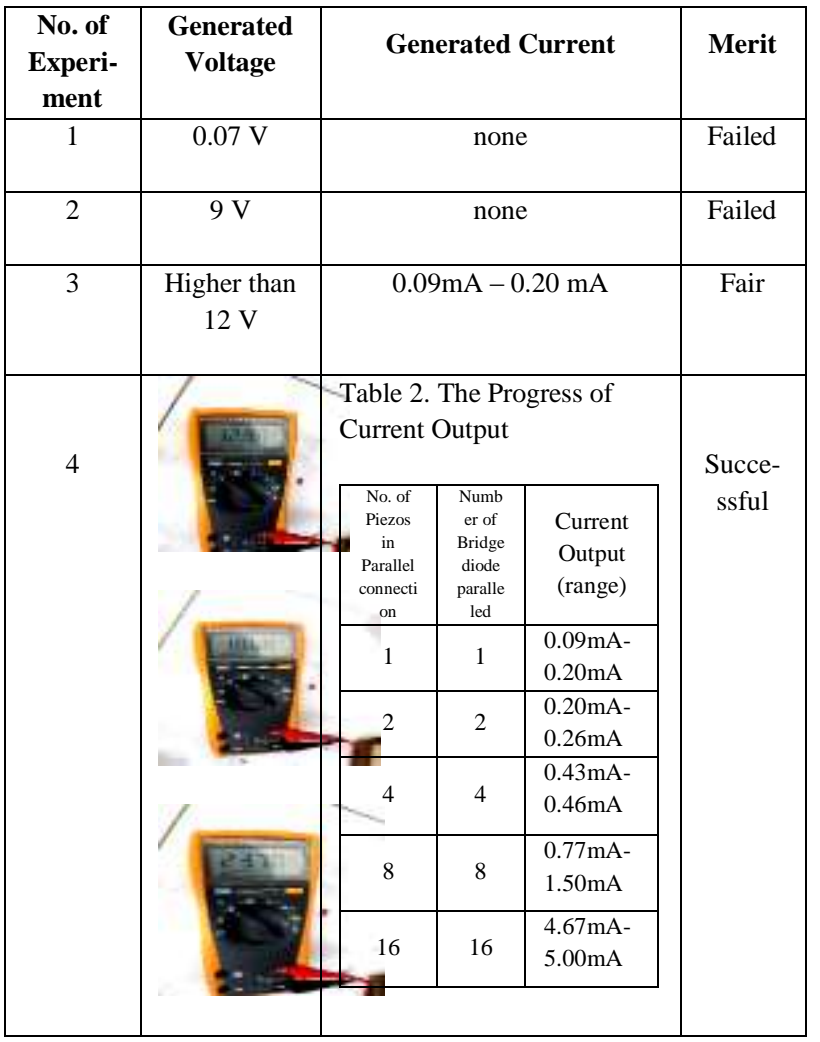

Based on results in table 1 the following figure shows the development of whole project.

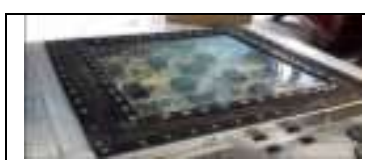

Figure 1.1 Walkergy pad(closed)

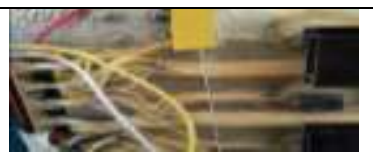

Figure 1.3 Internal Body of Walkergy Pad

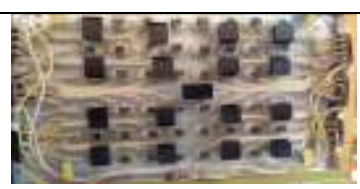

Figure 1.4 connection of Piezo and bridge diode

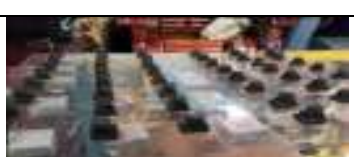

Figure 1.5 Pushers

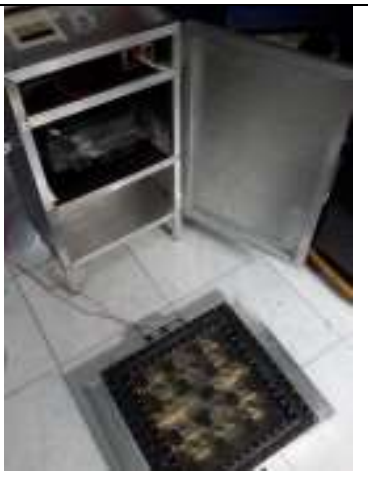

Figure 1.6 The whole Project 
Proc. of the Intl. Conf. on Advances in Applied science and Environmental Technology - ASET 2015.

Copyright (C) Institute of Research Engineers and Doctors, USA .All rights reserved.

ISBN: 978-1-63248-040-8 doi: 10.15224/ 978-1-63248-040-8-51

2. What is the projected generation of Walkergy pad in changing rate and generating voltage in terms of:

2.1. Walking?

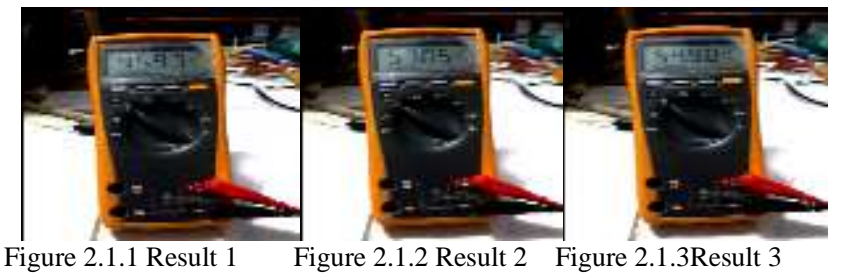

2.2. Running?

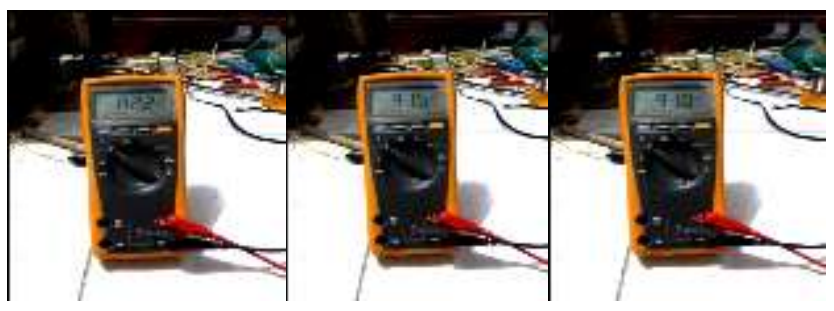

Figure 2.2.1 Result $1 \quad$ Figure 2.2.2 Result 2 Figure 2.2.3 Result 3

2.3 Jumping?

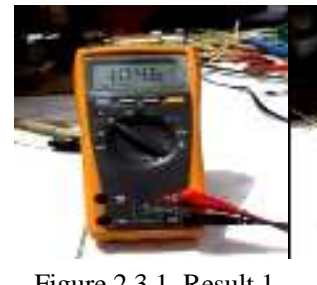

Figure 2.3.1. Result 1

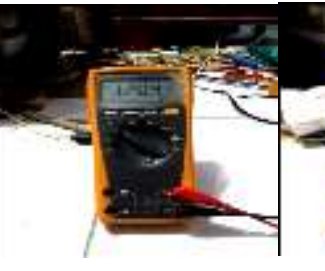

Figure 2.3.2 Result 2

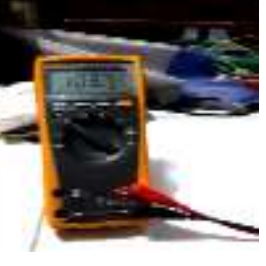

Figure 2.3.3 Result 3
3. What is the significant benefit of Walkergy Pad for an Average Energy House Consumption?

\begin{tabular}{|c|c|c|c|c|}
\hline Quantity & $\begin{array}{c}\text { Name of } \\
\text { Appliances }\end{array}$ & Wattages & $\begin{array}{c}\text { Computations of } \\
\text { Energy House Cost }\end{array}$ & $\begin{array}{c}\text { Computations of } \\
\text { Energy Savings in } \\
\text { Peso }(\mathrm{P})\end{array}$ \\
\hline 2 pcs. & Fluorescent & 100 & \multirow{3}{*}{$\begin{array}{l}\text { - } 295 \mathrm{~W} / 220 \mathrm{~V}= \\
134 \mathrm{~A}, \\
\text { - } 295 \mathrm{~A} \times 30 \mathrm{Mos} .= \\
8,850 \mathrm{~A} / 1000= \\
8.85 \mathrm{~kW}\end{array}$} & \multirow{3}{*}{$\begin{array}{l}\text { Load }=295 \mathrm{~W} \\
130 \mathrm{Ah}=2 \times 65 \mathrm{Ah} \\
\text { Charging } \\
\text { rate }=8 \mathrm{~A}(4 \mathrm{pad}) \\
\text { Inverter }=500 \mathrm{~W} \\
\text { Charging time = } \\
16 \mathrm{hrs} . \\
\text { Discharge time = } \\
\text { 5hrs. }\end{array}$} \\
\hline $1 \mathrm{pc}$. & Television & 75 & & \\
\hline $1 \mathrm{pc}$. & Electric fan & 120 & & \\
\hline \multicolumn{2}{|c|}{ TOTAL } & 295 & P $1,192.68$ & Savings $=\mathrm{P} 496.95$ \\
\hline
\end{tabular}

\section{Conclusions}

1. The generated Walkergy developed within fourth experimentation with the ratio of $1: 1$ pertaining to one bridge diode for each piezos.

2. The Walkergy Pad generate energy through walking, running and jumping with $51.3 \mathrm{~V}$ or $1 \mathrm{~A}-2 \mathrm{~A}$, $88.23 \mathrm{~V}$ or $2 \mathrm{~A}-3 \mathrm{~A}$, and $109 \mathrm{~V}$ or $2 \mathrm{~A}-3 \mathrm{~A}$ charging rate respectively.

3. The Walkergy Energy Supplement will save amounting Php496.95 of average energy house consumption.

\section{Bibliography}

http://www.nanomotion.com/piezo-

ceramic-motor-technology/piezoelectriceffect

http://www.myenergygateway.org/whatsup/5-types-renewable-energy http://www.scribd.com/doc/125123138/Pie zo-Power-Gen

http://environment.nationalgeographic.co $\mathrm{m} /$ environment/global-warming/solarpower-profile/ http://earthwealth.blogspot.com/2010_09_01_archive. html

http://www.dailymail.co.uk/sciencetech/art icle-2331550/The-SHOES-charge-iPhonewalk.html http://techaloo.com/shoecharger-innovator-mr-mandar-tulankar/ http://www.sciencealert.com.au/features/2 0140406-25615-2.html

Research Coordinator
Author of Books
Statistician of Research


Proc. of the Intl. Conf. on Advances in Applied science and Environmental Technology - ASET 2015.

Copyright (C) Institute of Research Engineers and Doctors, USA .All rights reserved.

ISBN: 978-1-63248-040-8 doi: 10.15224/ 978-1-63248-040-8-51
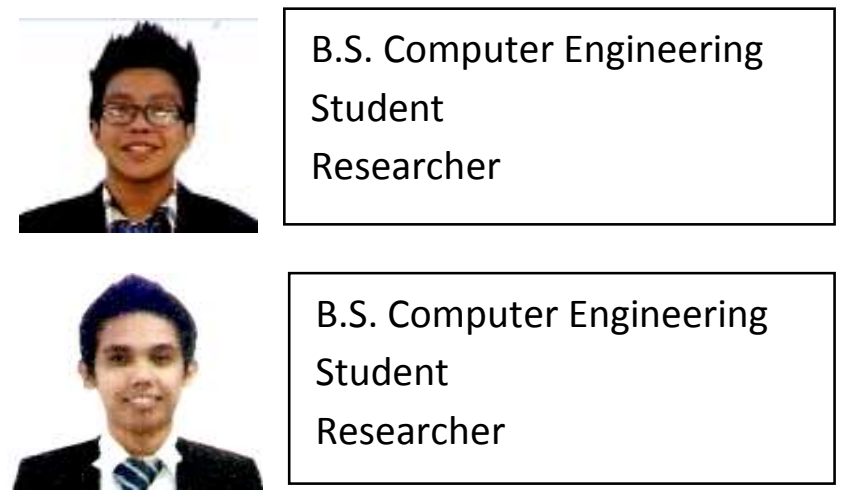

B.S. Computer Engineering

Student

Researcher 